\title{
AWARENESS OF DENTISTS ABOUT MEDICATION ERRORS
}

Sangeetha P1, Prabhawati P I ${ }^{2}$, Inamadar P I ${ }^{3}$,

\section{HOW TO CITE THIS ARTICLE:}

Sangeetha P, Prabhawati P. I, Inamadar P. I. "Awareness of dentists about medication errors: a pilot study". Journal of Evolution of Medical and Dental Sciences 2014; Vol 3, Issue 02, January 13; Page: 488-494, DOI:10.14260/jemds/2014/1854

ABSTRACT: OBJECTIVE: To assess the awareness of medication errors among dentists. METHODS: Medication errors are the most common single preventable cause of adverse events in medication practice. We conducted a survey with a sample of sixty dentists. Among them 30 were general dentists (BDS) and 30 were dental specialists (MDS). Questionnaires were distributed to them with questions regarding medication errors and they were asked to fill up the questionnaire. Data was collected and subjected to statistical analysis using Fisher exact and Chi square test. RESULTS: In our study, sixty percent of general dentists and $76.7 \%$ of dental specialists were aware about the components of medication error. Overall $66.7 \%$ of the respondents in each group marked wrong duration as the dispensing error. Almost thirty percent of the general dentists and $56.7 \%$ of the dental specialists felt that technologic advances could accomplish diverse task in reducing medication errors. This was of suggestive statistical significance with a $P$ value of 0.069 . CONCLUSION: Medication errors compromise patient confidence in the health-care system and increase health-care costs. Overall, the dental specialists were more knowledgeable than the general dentists about the Medication errors.

KEY WORDS: Medication errors; Dosing error; Prevention of errors; Adverse drug events; Prescribing errors; Medical errors.

INTRODUCTION: Medication error occurs in all parts of the medication use system.The potential for adverse drug events and medication errors have increased, as almost everyone in the modern world takes medication at one time or another. ${ }^{1}$ However, the unique characteristics of dental pharmacotherapy limit the likelihood of adverse drug events. ${ }^{2}$

Medication errors are unintentional errors in the prescribing, dispensing, or administration of a medicine while under the control of a healthcare professional, patient or consumer. They are the most common single preventable cause of adverse events in medication practice.

\begin{tabular}{|c|c|l|}
\hline \multicolumn{2}{|c|}{ Types } & \multicolumn{1}{c|}{ Types of Medication Errors $3,4,5$} \\
\hline 1 & Prescribing error & $\begin{array}{l}\text { Definition } \\
\text { Incorrect drug selection (based on indications, contraindications, known } \\
\text { allergies, existing drug therapy, and other factors), dose, dosage form, } \\
\text { use of a drug product ordered or authorized by physician or other } \\
\text { legitimate prescriber); illegible prescriptions or medication orders that } \\
\text { lead to errors that reach the patient }\end{array}$ \\
\hline 2 & Omission error & $\begin{array}{l}\text { The failure to administer an ordered dose to a patient before the next } \\
\text { scheduled dose, if any }\end{array}$ \\
\hline 3 & Wrong time error & Administration of medication outside a predefined time interval from its \\
\hline
\end{tabular}




\begin{tabular}{|c|c|c|}
\hline & & $\begin{array}{l}\text { scheduled administration time (this interval should be established by } \\
\text { each individual health care facility) }\end{array}$ \\
\hline 4 & $\begin{array}{l}\text { Unauthorized drug } \\
\text { errors }\end{array}$ & $\begin{array}{l}\text { Administration to the patient of medication not authorized by a } \\
\text { legitimate prescriber for the patient }\end{array}$ \\
\hline 5 & $\begin{array}{l}\text { Improper dose } \\
\quad \text { error }\end{array}$ & $\begin{array}{l}\text { Administration to the patient of a dose that is greater than or less than } \\
\text { the amount ordered by the prescriber or administration of duplicate } \\
\text { doses to the patient, i.e., one or more dosage units in addition to those } \\
\text { that were ordered }\end{array}$ \\
\hline 6 & $\begin{array}{l}\text { Wrong dosage- } \\
\text { form errors }\end{array}$ & $\begin{array}{l}\text { Administration to the patient of a drug product in a different dosage form } \\
\text { than ordered by the prescriber }\end{array}$ \\
\hline 7 & $\begin{array}{l}\text { Wrong drug- } \\
\text { preparation error }\end{array}$ & $\begin{array}{l}\begin{array}{l}\text { Drug product incorrectly formulated or manipulated before } \\
\text { administration }\end{array} \\
\end{array}$ \\
\hline 8 & $\begin{array}{l}\text { Wrong } \\
\text { administration- } \\
\text { technique error }\end{array}$ & $\begin{array}{l}\text { Inappropriate procedure or improper technique in the administration of } \\
\text { a drug }\end{array}$ \\
\hline 9 & $\begin{array}{l}\text { Deteriorated drug } \\
\text { error }\end{array}$ & $\begin{array}{l}\text { Administration of a drug that has expired or for which the physical or } \\
\text { chemical dosage-form } \\
\text { integrity has been compromised }\end{array}$ \\
\hline 10 & Monitoring error & $\begin{array}{l}\text { Failure to review a prescribed regimen for appropriateness and detection } \\
\text { of problems, or failure } \\
\text { to use appropriate clinical or laboratory data for adequate assessment of } \\
\text { patient response to prescribed therapy }\end{array}$ \\
\hline 11 & Compliance error & $\begin{array}{l}\text { Inappropriate patient behavior regarding adherence to a prescribed } \\
\text { medication regimen }\end{array}$ \\
\hline 12 & $\begin{array}{l}\text { Other medication } \\
\text { error }\end{array}$ & $\begin{array}{l}\text { Any medication error that does not fall into one of above predefined } \\
\text { categories }\end{array}$ \\
\hline
\end{tabular}

Dental practitioners are responsible for prescribing drugs to their patients as a part of dental treatment. There are a limited number of drugs routinely used in dental therapeutics. Most dentists are very knowledgeable about the contraindications, interactions and adverse effects of the medications that compose their own therapeutic arsenals. Hence, the knowledge of medication errors and the need to obtain reliable new information in this regard is a constant challenge for practicing dentists. 2,6

Oral healthcare professionals share the responsibility of identifying contributing factors to medication errors and using that knowledge to reduce their occurrence. Despite the numerous studies and the staggering error statistics there is extremely limited information in the literature with regard to the subject of medication errors in dentistry. This article emphasizes gaps in the knowledge of dental practitioners about medication errors.

MATERIALS AND METHODS: This study was conducted in October 2008 at an urban teaching hospital using a questionnaire as the survey instrument. Dentists were randomly selected and structured questionnaires in the form of multiple-choice questions were handed over to them. The knowledge about medication errors was analyzed by comparing the responses of the general 
dentists and the dental specialists. Demographic questions measured respondents' age, sex, level of training, whether they were in private or academic practice, and the percentage of time in clinical practice and time spent in caring hospitalized patients. The data were analyzed by subjecting them to Statistical analysis using $\chi^{2}$ test or Fisher's exact test.

RESULTS: In our study, sixty percent of general dentists and $76.7 \%$ of dental specialists were aware about the components of medication error. A similar percentage (76.7\%) of dental specialists and $53.3 \%$ of general dentists identified all the errors of prescription writing which was of suggestive statistical significance with a P value of 0.058 . Forty percent of general dentists and $60 \%$ of dental specialists did not know about transcribing error. Overall $66.7 \%$ of the respondents in each group marked wrong duration as the dispensing error. Drug omission was the administration error according to $40 \%$ of general dentists and $66.7 \%$ of dental specialists and was statistically significant with a p P value of 0.038 . Approximately $47 \%$ of general dentists and $56.7 \%$ of dental specialists agreed that medication errors could be reduced through various sources of information technology. On the contrary, $40 \%$ of general dentists and $13.3 \%$ of dental specialist did not know about this fact, which was statistically significant with a $\mathrm{P}$ value of 0.020 . Almost thirty percent of the general dentists and $56.7 \%$ of the dental specialists felt that technologic advances could achieve diverse task in reducing medication errors. This was of suggestive statistical significance with a P value of 0.069 .

DISCUSSION: There are several nodes or parts of the medication use process where errors can occur. These include prescribing, transcribing, dispensing, administering. ${ }^{7}$ Majority of our participants were well aware that medication errors included the entire spectrum from prescribing through to administering. The dental specialists (76.7\%) fared better than the general dentists $(60 \%)$ did.

The majority of medication errors occur because of poor prescribing. Most of the research to date has been skewed on prescribing errors. ${ }^{8,9,10}$ In the current study majority of general dentists (53.3\%) and dental specialists (76.7\%) identified all the causes of prescribing errors. A statistically significant percentage of general dentists $33.3 \%$ and dental specialists $13.3 \%$ felt that 'wrong dose' constituted prescribing error. Electronic prescribing may help reduce the risk of prescribing errors owing to illegible handwriting, although such systems can in turn lead to further problems such as incorrect drug selection etc which requires further study. 8,9,10

Transcription is the transfer of information from an order sheet to nursing documentation forms. Transcribing error is a source of many medication errors. ${ }^{11,12}$

In our study $26.7 \%$ of general dentists and $20 \%$ of dental specialists felt that an incomplete order accounted for transcription error. None of the participants recognized all the contributing factors of transcribing error.

Dispensing errors generally refers to errors in the dispensing process. It occurs at any stage of the dispensing process, from the receipt of the prescription in the pharmacy to the supply of a dispensed medicine to the patient. ${ }^{13}$ Almost $66.7 \%$ of general dentists and $66.7 \%$ of dental specialists considered wrong duration as the dispensing error. Only 3\% of dental specialists identified all the causes of dispensing errors.

Before administering a medication, the health care professional not only should check for the five rights but should also know the proper administration technique for each medication. Drug 
administration errors largely involve errors of omission where the drug is not administered for a variety of reasons. ${ }^{7}$ Majority of the dental specialists (66.7\%) and $40 \%$ of the general dentists in our study felt the same which was found to be statistically significant. Only $13.3 \%$ of general dentists and $3.3 \%$ of dental specialists marked all the elements of administration error.

Information technology interventions have great potential for reducing the frequency of errors. Virtually all the publications on medication errors identify opportunities for systematic changes to reduce the risk of future errors. Many believe that the use of information technology can capture medication errors and prevent subsequent ADEs (Adverse Drug Events ). ${ }^{14,15,16}$ We found that $46.7 \%$ of the general dentists and $56.7 \%$ of the dental specialists believed that information technology could decrease medication errors. A statistically significant percentage of our participants were not informed about error reduction through information technology. Approximately $27 \%$ of our participants think that technologic advances could decrease if not eliminate errors, but majority of the general dentists (33.3\%) and the dental specialists (56.7\%) were aware that technologic advances could achieve various error reduction tasks, which was of suggestive statistical significance.

An understanding of medication errors is important in dental education as continual learning is a lifetime enterprise for anyone in a health-related profession. Dental practitioners should look forward to reduce medication errors in their institutions and day-to-day practice

CONCLUSION: Medications can greatly improve health when used wisely and correctly. Remember that using medications to help patients is not a risk-free activity. Medication errors are an unfortunate part of the health care delivery system. Health care provider attitudes must change in the approach to prevention of these errors. Know your responsibilities and work hard to make medication use safe for your patients. Yet, medication error is common and is causing preventable human suffering and financial cost. Patient education is an important aspect of any program to prevent medication misadventures.

Our findings dictate the need for greater understanding of all the aspects of medication errors among dental professionals. Overall, the dental specialists were more informed about the Medication errors than the general dentists.

\section{BIBLIOGRAPHY:}

1. Cohen MR. Medication errors: prevention and management issues. Platform presentation of the American Pharmaceutical Association Annual Meeting; March 10-14, 2000; Washington, DC.

2. Moore PA, Gage TW, Hersh EV, Yagiela JA, Haas DA. Adverse drug interactions in dental practice. Professional and educational implications. JADA 1999 Jan; 130: 47-54.

3. Davis NM, Cohen MR. Medication errors: causes and prevention. Huntingdon Valley, PA: Neil M. Davis Associates; 1981

4. Lesar RS, Bricel and LL, Delcoure K, et al. Medication prescribing errors in a teaching hospital. JAMA. 1990; 263:2329-34

5. American Society of Hospital Pharmacists. ASHP statement on the pharmacist's clinical role in organized health care settings. Am J Hosp Pharm. 1989;46:2345-6. 
6. CL Marek. Avoiding prescribing errors: a systematic approach. J Am Dent Assoc1996; 127; 617-623.

7. Williams DJP. Medication errors. J R Coll Physicians Edinb2007; 37:343-346.

8. Barber N, Rawlins M, Dean Franklin B. Reducing prescribing error: competence, control, and culture. QualSaf Health Care 2003; 12 (Suppl 1):i29-32.

9. Dean B, Schachter M, Vincent C, Barber N. Causes of prescribing errors in hospital inpatients: a prospective study. Lancet2002; 359(9315):1373-8.

10. Dean B, SchachterM,Vincent C, Barber N. Prescribing errors in hospital inpatients: their incidence and clinical significance. QualSaf Health Care2002; 11(4):340-4.

11. O'Shea E. Factors contributing to medication errors: a literature review. J ClinNurs 1999 Sep; 8(5):496-504.

12. Pichon $\mathrm{R}$, Zelger GL, Wacker $\mathrm{P}$, et al. Analysis and quantification of prescribing and transcription errors in a paediatric oncology service. Pharm World Sci 2002; 24:12-15.

13. Peterson GM, Bergin JK; Pharmacists attitudes towards dispensing errors: their causes and prevention. Clin Pharm Ther, 1999 Feb; 24 (1):57-71.

14. Wang JK, Herzog NS, Kaushal R, Park C, Mochizuki C, Scott R, et al.Prevention of Pediatric Medication Errors by Hospital Pharmacists and the Potential Benefit of Computerized Physician Order Entry. Pediatrics 2007 Jan; 119 (1): e77-e85.

15. Bates DW, Cohen M, Leape LL, Overhage JM, Shabot MM, Sheridan T. Reducing the frequency of errors in medicine using information technology. J Am Med Inform Assoc 2001; 8: 299-308.

16. Kaushal R, Barker KN, Bates WD. How Can Information Technology Improve Patient Safety and Reduce Medication Errors in Children's Health Care? Arch Pediatr Adolesc Med. 2001; 155:1002-1007.

\begin{tabular}{|l|l|c|c|c|}
\hline \multirow{4}{*}{ Questions } & \multicolumn{1}{|c|}{ Response } & $\begin{array}{c}\text { General } \\
\text { dentists } \\
\text { (n=30) }\end{array}$ & $\begin{array}{c}\text { Dental } \\
\text { specialists } \\
\text { (n=30) }\end{array}$ & $\begin{array}{c}\text { P } \\
\text { value }\end{array}$ \\
\hline \multirow{5}{*}{$\begin{array}{l}\text { What do you understand by } \\
\text { medication errors? }\end{array}$} & 1. Prescribing error & $6(20 \%)$ & $3(10 \%)$ & 0.472 \\
\cline { 2 - 5 } & 2. Administrating errors & $2(6.7 \%)$ & $1(3.3 \%)$ & 1.000 \\
\cline { 2 - 5 } & 3. Transcribing error & $0(0 \%)$ & $2(6.7 \%)$ & 0.492 \\
\cline { 2 - 5 } & 4. Dispensing error & $0(0 \%)$ & $0(0 \%)$ & - \\
\cline { 2 - 5 } & 5. Administration error & $0(0 \%)$ & $0(0 \%)$ & - \\
\cline { 2 - 5 } & 6. All of the above & $18(60 \%)$ & $23(76.7 \%)$ & 0.165 \\
\cline { 2 - 5 } & 7. None of the above & $0(0 \%)$ & $0(0 \%)$ & - \\
\cline { 2 - 5 } & 8. Don't know & $4(13.3 \%)$ & $1(3.3 \%)$ & 0.353 \\
\hline \multirow{5}{*}{ Prescribing error: is caused } & 1. Wrong drug & $2(6.7 \%)$ & $1(3.3 \%)$ & 1.000 \\
\cline { 2 - 5 } & 2. Wrong dose & $10(33.3 \%)$ & $4(13.3 \%)$ & $0.067+$ \\
\cline { 2 - 5 } & 3. Wrong frequency & $0(0 \%)$ & $1(3.3 \%)$ & 1.000 \\
\cline { 2 - 5 } & 4. Wrong route & $0(0 \%)$ & $0(0 \%)$ & - \\
\cline { 2 - 5 } & 5. Illegible Writing & $0(0 \%)$ & $0(0 \%)$ & - \\
\cline { 2 - 5 } & 6. All of the above & $16(53.3 \%)$ & $23(76.7 \%)$ & $0.058+$ \\
\cline { 2 - 5 } & 7. None of the above & $0(0 \%)$ & $0(0 \%)$ & - \\
\cline { 2 - 5 } & 8. Don't know & $2(6.7 \%)$ & $1(3.3 \%)$ & 1.000 \\
\hline
\end{tabular}


ORIGINAL ARTICLE

Transcribing error: Data entry error

\begin{tabular}{|c|c|c|c|}
\hline 1. Illegible signature & $2(6.7 \%)$ & $(0 \%)$ & 0.492 \\
\hline 2. Time missing & $0(0 \%)$ & $3(10 \%)$ & 0.237 \\
\hline 3. Order incomplete & $8(26.7 \%)$ & $6(20 \%)$ & 0.761 \\
\hline 4. Order illegible & $4(13.3 \%)$ & $0(0 \%)$ & 0.112 \\
\hline 5. All the above & $0(0 \%)$ & $0(0 \%)$ & - \\
\hline 6. None of the above & $0(0 \%)$ & $2(6.7 \%)$ & 0.492 \\
\hline 7. Don't know & $12(40 \%)$ & $18(60 \%)$ & 0.121 \\
\hline 1. Drug omission & $2(6.7 \%)$ & $3(10 \%)$ & 1.000 \\
\hline 2. Wrong drug dose form & $0(0 \%)$ & $1(3.3 \%)$ & 1.000 \\
\hline 3. Wrong labeling & $6(20 \%)$ & $2(6.7 \%)$ & 0.254 \\
\hline 4. Wrong quantity & $2(6.7 \%)$ & $1(3.3 \%)$ & 1.000 \\
\hline 5. Inadequate quality & $0(0 \%)$ & $0(0 \%)$ & - \\
\hline 6. Wrong duration & $20(66.7 \%)$ & $20(66.7 \%)$ & 1.000 \\
\hline 7. All of the above & $0(0 \%)$ & $1(3.3 \%)$ & 1.000 \\
\hline 8. None of the above & $0(0 \%)$ & $2(6.7 \%)$ & 0.492 \\
\hline 9. Don't know & $0(0 \%)$ & $0(0 \%)$ & - \\
\hline 1. Wrong administration & $0(0 \%)$ & $0(0 \%)$ & - \\
\hline 2. Wrong delivery & $2(6.7 \%)$ & $2(6.7 \%)$ & 1.000 \\
\hline 3. Wrong frequency & $6(20 \%)$ & $1(3.3 \%)$ & 0.103 \\
\hline 4. Wrong dosing & $0(0 \%)$ & $1(3.3 \%)$ & 1.000 \\
\hline 5. Omission & $12(40 \%)$ & $20(66.7 \%)$ & $0.038^{*}$ \\
\hline 6. All of the above & $4(13.3 \%)$ & $1(3.3 \%)$ & 0.353 \\
\hline 7. None of the above & $6(20 \%)$ & $6(20 \%)$ & 1.000 \\
\hline 8. Don't know & $0(0 \%)$ & $0(0 \%)$ & - \\
\hline $\begin{array}{l}\text { 1. Computerized physician } \\
\text { order entry }\end{array}$ & $4(13.3 \%)$ & $3(10 \%)$ & 0.353 \\
\hline 2. Bar coding & $0(0 \%)$ & $2(6.7 \%)$ & 0.492 \\
\hline 3. Personal digital assistants & $0(0 \%)$ & $2(6.7 \%)$ & 0.492 \\
\hline 4. Internet & $0(0 \%)$ & $1(3.3 \%)$ & 1.000 \\
\hline 5. All of the above & $14(46.7 \%)$ & $17(56.7 \%)$ & 0.438 \\
\hline 6. None of the above & $0(0 \%)$ & $1(3.3 \%)$ & 1.000 \\
\hline 7. Don't know & $12(40 \%)$ & $4(13.3 \%)$ & $0.020^{*}$ \\
\hline $\begin{array}{l}\text { 1. Decrease if not eliminate } \\
\text { errors }\end{array}$ & $8(26.7 \%)$ & $8(26.7 \%)$ & 1.000 \\
\hline $\begin{array}{l}\text { 2. Eliminate human } \\
\text { miscalculations }\end{array}$ & $6(20 \%)$ & $2(6.7 \%)$ & 0.254 \\
\hline $\begin{array}{l}\text { 3. Warning doses is too large } \\
\text { or small }\end{array}$ & $0(0 \%)$ & $0(0 \%)$ & - \\
\hline $\begin{array}{l}\text { 4. Warning - potentially } \\
\text { harmful medication } \\
\text { interaction }\end{array}$ & $0(0 \%)$ & $0(0 \%)$ & - \\
\hline 5. Warning - Allergy & $0(0 \%)$ & $0(0 \%)$ & - \\
\hline 6. All of the above & $10(33.3 \%)$ & $17(56.7 \%)$ & $0.069+$ \\
\hline
\end{tabular}

Dispensing error: Is caused by the pharmacists

Administration error: Are caused by the nurse or parent

Reducing medication error through technology

Technologic advances can 


\begin{tabular}{|l|c|c|c|}
\hline 7. None of the above & $2(6.7 \%)$ & $1(3.3 \%)$ & 1.000 \\
\hline 8. Don't know & $4(13.3 \%)$ & $2(6.7 \%)$ & 0.671 \\
\hline
\end{tabular}

Table 1: Comparison of Knowledge regarding the medication errors in two groups of subjects studied

\begin{tabular}{|l|c|c|c|}
\hline \multicolumn{1}{|c|}{ Questions } & $\begin{array}{c}\text { General dentists } \\
(\mathbf{n = 3 0 )}\end{array}$ & $\begin{array}{c}\text { Dental specialists } \\
(\mathbf{n = 3 0 )}\end{array}$ & P value \\
\hline 1. What do u understand by medication errors? & $18(60.0 \%)$ & $23(76.7 \%)$ & 0.165 \\
\hline 2. Prescribing error: is caused by the doctor & $16(53.3 \%)$ & $23(76.7 \%)$ & 0.165 \\
\hline 3. Transcribing error: Data entry error & 0 & 0 & - \\
\hline 4. Dispensing error: Is caused by the pharmacists & 0 & $1(3.3 \%)$ & 1.000 \\
\hline $\begin{array}{l}\text { 5. Administration error: Are caused by } \\
\text { the nurse or parent }\end{array}$ & $4(13.3 \%)$ & $1(3.3 \%)$ & 0.353 \\
\hline 6. Reducing medication error through technology & $14(46.7 \%)$ & $17(56.7 \%)$ & 0.438 \\
\hline 7. Technologic advances can & $10(33.3 \%)$ & $17(56.7 \%)$ & $0.069+$ \\
\hline \multicolumn{2}{|r|}{ Table 2: Comparison of Knowledge regarding the medication } \\
errors in two groups of subjects studied (Correct answers)
\end{tabular}

Chi-square test/2x2 Fisher Exact test

\section{AUTHORS:}

1. Sangeetha P.

2. Prabhawati P. I.

3. Inamadar P.I.

\section{PARTICULARS OF CONTRIBUTORS:}

1. Assistant Professor, Department of Paediatric Dentistry, M.R. Ambedkar Dental College, Bangalore, Karnataka, India.

2. Reader, Department of Paediatric Dentistry, Al-Ameen Dental College, Bijapur, Karnataka.

3. Professor and Head, Department of Forensic Medicine, Hassan Institute of Medical Science, Hassan, Karnataka.

\section{NAME ADRRESS EMAIL ID OF THE CORRESPONDING AUTHOR:}

Dr. Prabhawati P.I.,

Reader, Department of Pedodontics, Al-Ameen Dental College, Bijapur -3, Karnataka, India.

Email - pedooshin@gmail.com

Date of Submission: 15/11/2013.

Date of Peer Review: 16/11/2013.

Date of Acceptance: 27/11/2013.

Date of Publishing: 10/01/2014 